\title{
The influence of environmental variables in the reproductive performance of Macrobrachium amazonicum (Heller, 1862) (Caridea: Palaemonidae) females in a continental population
}

\author{
JOÃO ALBERTO F. PANTALẼ̃O", ABNER CARVALHO-BATISTA, \\ SARAH S.A. TEODORO and ROGÉRIO C. COSTA
}

\begin{abstract}
Departamento de Ciências Biológicas, Laboratório de Biologia de Camarões Marinhos e de Água Doce, Faculdade de Ciências, Universidade Estadual Paulista/UNESP, Av. Engenheiro Luiz Edmundo Carrijo Coube, 14-01, Vargem Limpa, 17033-360 Bauru, SP, Brazil
\end{abstract}

Manuscript received on April 13, 2017; accepted for publication on October 13, 2017

\begin{abstract}
Macrobrachium amazonicum is a commercially important freshwater prawn with a high degree of reproductive plasticity. The species is classified into two groups: coastal populations, with larger individuals exhibiting high fecundity and needing brackish water for larval development; and continental populations, with smaller specimens exhibiting low fecundities and completing metamorphosis in freshwater. The objective of this study was to investigate the influence of environmental factors in the fecundity, egg size and volume, and reproductive output in females of M. amazonicum from a continental population during a two-year period. We also compared our results with those obtained for other continental and coastal populations. Reproductive parameters differed markedly between continental and coastal populations in most cases. The continental population studied here, however, exhibited reproductive characteristics similar to those of coastal populations. The present study found a correlation between the reproductive parameters and the environmental variables analyzed. This result corroborates the hypothesis that wide variation in reproductive parameters in the geographical distribution of $M$. amazonicum is related to the environmental characteristics in which populations are inserted. We suggest that further studies could investigate the potential of continental populations for aquaculture, which could significantly reduce production costs.
\end{abstract}

Key words: Amazon river prawn, shrimp, Tietê, abiotic factors, reproductive output.

\section{INTRODUCTION}

Reproduction is one of the most important life

Correspondence to: João Alberto Farinelli Pantaleão

E-mail: pantaleaojaf@gmail.com

*Present address: Departamento de Engenharia Ambiental, Instituto de Ciências Tecnológicas e Exatas, Universidade Federal do Triângulo Mineiro/UFTM, Av. Dr. Randolfo Borges Júnior, 1250, Univerdecidade, 38064-200 Uberaba, MG, Brazil history events of all organisms (Yoshino et al. 2002). For crustaceans, the number and size of eggs, together with reproductive output, are important variables with several ecological implications, such as in size of newly hatched larvae; in size of sexual maturity; number of egg masses produced and whether the brood mass is partitioned into many small or few large eggs (Hines 1982, Scaico 1992, Meireles et al. 2013). 
The Amazon River prawn Macrobrachium amazonicum (Heller, 1862) is widely distributed in South America, from Venezuela to Argentina; it inhabits lacustrine, flood-plain, and lotic environments in tropical and subtropical flatlands (Maciel and Valenti 2009). The species is present in all main eastern river basins (Orinoco, Amazon, Araguaia-Tocantins and São Francisco), including isolated inland populations from the upper Paraná and Paraguay River Systems (Maciel and Valenti 2009, Pantaleão et al. 2012, 2014). In general, M. amazonicum breeds throughout the year, with reproductive peaks during the rainy season (Maciel and Valenti 2009).

Macrobrachium amazonicum can be classified into two distinct groups (Moraes-Valenti and Valenti 2010): coastal populations, which inhabit rivers close to estuarine waters; and continental populations, which live in rivers, lakes and other water bodies in inland areas of South America. Coastal populations are large (100-160 mm of total length), exhibit high fecundity (thousands of eggs), need brackish water for larval development and males can develop into four morphotypes; continental populations are smaller $(\sim 50 \mathrm{~mm}$ of total length), exhibit low fecundity (hundreds of eggs) and complete metamorphosis in freshwater (Moraes-Valenti and Valenti 2010).

Global temperature and precipitation patterns have changed and are predicted to change even more due to anthropogenically driven climate change (Meehl et al. 2007, Jeppesen et al. 2015). Climate change may influence reproductive performance in crustaceans because their patterns of life history are influenced by environmental conditions (Costa and Negreiros-Fransozo 1998). Environmental factors can have an effect on the reproductive parameters of $M$. amazonicum, and the variation previously observed seems to be related to the species' wide geographical distribution (e.g. Maciel and Valenti 2009, Meireles et al. 2013). For instance, the egg size in each brood varies according to the distance of the breeding site from the sea, and a progressive divergence of the continental and coastal populations had been suggested (OdinetzCollart and Rabelo 1996, Maciel and Valenti 2009). These conclusions were made by comparing the results obtained for different regions and different populations (coastal and continental). However, no study has yet investigated the effects of the variation of environmental factors on the same population.

Macrobrachium amazonicum is the freshwater decapod of greatest economic importance in the Eastern South American subcontinent (Maciel and Valenti 2009). To date, the studied population represents the only exception for continental populations in which all four male morphotypes were found (Pantaleão et al. 2014), indicating that continental specimens can reach body sizes similar to those of coastal populations. In this context, the knowledge on the intraspecific variations that allow this species to complete its life cycle both in estuarine and continental waters is of great importance for their cultivation. The objective of this study was to investigate how environmental factors influence fecundity, egg size and volume, and reproductive output in females of M. amazonicum during a two-year period. We also compared our results with those obtained for other continental and coastal populations.

\section{MATERIALS AND METHODS}

\section{ENVIRONMENTAL FACTORS}

The water temperature $\left({ }^{\circ} \mathrm{C}\right)$ and $\mathrm{O}_{2}$ concentration $\left(\mu \mathrm{g} . \mathrm{L}^{-1}\right)$ were obtained monthly with a digital multimeter (Politerm RS-232, São Paulo, Brazil) at the sampling location. Subsurface water samples (approximately $20 \mathrm{~cm}$ ) were collected in order to measure $\mathrm{pH}(\mathrm{pH}$ meter) and Chlorophyll-a concentration $\left(\mu \mathrm{g} . \mathrm{L}^{-1}\right)$. The proceedings to estimate the Chlorophyll-a concentration followed Golterman et al. (1978). Data on monthly rainfall were obtained from www.climate-data.org. 


\section{SAMPLING SITE}

The samples were conducted in the lower of the Ibitinga Reservoir on the Tietê River. The dam is located in the municipality of Cambaratiba $\left(24^{\circ}\right.$ 44' 29" S; 49 01' 27' W), in the central-western region of the State of São Paulo, Brazil, in the basin of the Paraná River. The collection site was located downstream of the reservoir of Ibitinga Hydroelectric Power Plant, in a lotic environment with a sandy bottom and marginal vegetation consisting of grasses and aquatic macrophytes. The collection site was in a stretch of the Tietê River with great sports fishing activity.

\section{SAMPLING}

Females with embryos were sampled monthly from December 2011 to September 2013, during the day, from marginal vegetation and from the river bottom. We used a combination of a $60 \times 60$ $\mathrm{cm}^{2}$ sieve (2 mm knot-to-knot mesh size) and a trap similar to a "Matapi" (made of natural fiber), commonly used in the Amazon region in Brazil (see Odinetz-Collart 1993), but made of plastic material (Fig. 1). This trap was chosen in order to avoid a selective sampling, and it was placed near the macrophytes at 1-2 meter deep. The bait used for this sample was crushed corn and fish viscera. The time of each sampling method was 15 minutes for sieve and 30 for the trap. Immediately after sampling, individuals were stored in individual plastic bags with ice to preserve the eggs, and then transported to the Laboratory of Biology of Marine and Freshwater Shrimp (LABCAM) of UNESP, Bauru, São Paulo, where prawns were kept frozen until the analyses.

\section{REPRODUCTIVE PARAMETERS}

For each month, 20 females with embryos were haphazardly selected for analyses. When there were fewer than 20 individuals, all of them were measured. Females with embryos had their carapace

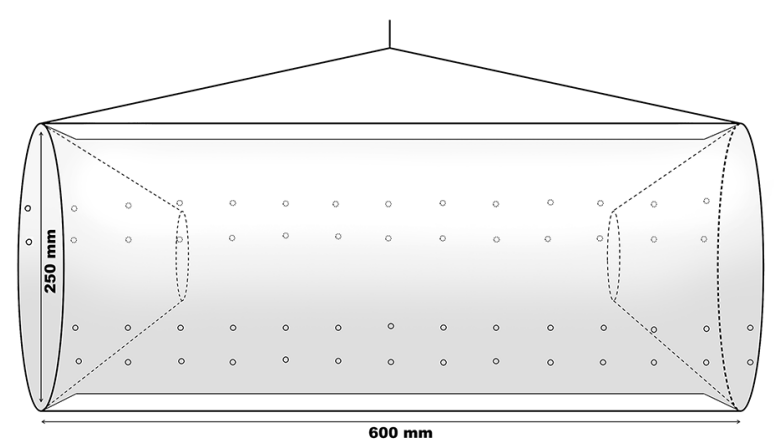

Figure 1 - Representation of the plastic trap used for collections of Macrobrachium amazonicum (Heller, 1862) at the studied region.

length (CL) measured as the distance between the orbital angle and the posterior margin of the carapace, with a digital caliper $(0.01 \mathrm{~mm})$. Embryos were classified according to the development stage as follows: Stage I, homogeneous color within the egg, no eye pigments visible; Stage II, eye pigments barely visible; Stage III, eyes fully developed (Wehrtmann 1990, García-Guerrero and Hendrickx 2009). Subsequently, ten eggs of each female were cautiously removed from the parental pleon and measured as length (longest axis) and width (shortest axis) under a microscope (Leica ICC50 HD, Wetzlar, Germany), with 100x magnification. The software LAS - Leica Application Suite, version 4.1.0, was used for image acquisition. Afterward, females were immersed in a sodium hypochlorite solution $(0.05 \%)$ and then the total number of embryos in each female was cautiously extracted with a fine forceps and then counted. Fecundity of each female was calculated (= number of embryos per female). We employed here the concept of realized fecundity (number of eggs attached under the abdomen) according to Anger and Moreira (1998).

Egg volume (EV) was calculated as: $\mathrm{EV}=\pi *$ $1 * \mathrm{~h} *(\mathrm{~h})^{2}$; where "l" is length; "h" width in mm and $\pi=3.14$ (Wehrtmann 1990). For estimation of reproductive output (RO), the entire egg mass and females' bodies were dried in an oven at $60{ }^{\circ} \mathrm{C}$ for 48 hours. RO was calculated by dividing the total 
dry egg mass by the female dry mass without the eggs, which was determined by an analytic balance (0.0001g precision) (Clarke et al. 1991). Following the recommendations of Zimmermann et al. (2015), RO was estimated only for females carrying early egg developmental stage (ES I), because the weight gain of females during egg incubation might lead to a subestimation of $\mathrm{RO}$ when calculating the regression of the egg mass weight on female body weight.

\section{STATISTICAL ANALYSES}

Assumptions of normality of distributions and homogeneity of variances were verified through Shapiro-Wilk and Levene's tests, respectively. The significance level for all statistical tests was set at $a=0.05$.

The seasons (rainy and dry) adopted for the studied location were based on Franchito et al. (2008), where the rainy season is set from October to March, and the dry season from April to September.

Differences in the environmental variables values, CL, EV in each ES and RO for each sampled season (rainy 1 , dry 1 , rainy 2 , dry 2 ) were compared using ANOVA or the non-parametric equivalent Kruskal-Wallis, followed by the post-hoc Tukey or Dunn (non-parametric) tests (Zar 1999). We ran all the analyses using linearized data (ln) to achieve normality and to the parametric test (ANOVA) be performable. When it was not possible, the equivalent non-parametric test (Kruskal-Wallis) was used. The applied test is indicated for each analyzed feature. The relationships fecundity/ CL, EV (in each stage)/CL and RO/CL were assessed with Linear Regressions (Zar 1999). We used the adjusted mean fecundity for correlations (Spearman) with the environmental factors to neutralize the effect of female size on fecundity. This methodology was based on the study of Nicola and Almodóvar (2002).
Linear regressions of log-transformed data (ln) were plotted for the number of eggs and CL. Subsequently, the Analysis of Covariance (ANCOVA; Zar 1999) was applied to determine the relationship between CL (independent variable) and fecundity (dependent variable), using the egg developmental stage (ES) and year seasons as covariables, to detect possible differences among fecundities in each ES or season.

\section{RESULTS}

\section{ENVIRONMENTAL FACTORS}

The water temperature ranged from 19.7 to $30{ }^{\circ} \mathrm{C}$ $\left(24.38 \pm 3.29^{\circ} \mathrm{C}\right)$. Higher values were observed in rainy seasons and there were statistically significant differences between rainy and dry seasons (ANOVA, $\mathrm{p}<0.05$ ) (Fig. 2).

Monthly rainfall of the studied region ranged from 0 to $332 \mathrm{~mm}^{3}\left(88.7 \pm 88.9 \mathrm{~mm}^{3}\right)$. There were statistically significant differences among all the sampled seasons (ANOVA, $\mathrm{p}<0.01$ ) (Fig. 2).

The chlorophyll-a concentration ranged from 0.26 to $51.8 \mu \mathrm{g} / 1(8.05 \pm 11.82 \mu \mathrm{g} / \mathrm{l})$. Values increased from the first rainy season compared to the other seasons. There were statistically significant differences among seasons (ANOVA, $p$ $<0.05$ ) (Fig. 2).

The $\mathrm{O}_{2}$ concentration ranged from 3.1 to 8.8 $\mathrm{mg} / \mathrm{l}(6.24 \pm 1.96 \mathrm{mg} / \mathrm{l})$. These values increased along the studied period, with statistically significant differences observed among seasons (Kruskal-Wallis, $\mathrm{p}<0.05$ ) (Fig. 2).

The $\mathrm{pH}$ ranged from 6.53 to $8.93(7.51 \pm 0.57)$ with a significant decrease in the mean values by seasons from the rainy season 1 to rainy season 2 (Kruskal-Wallis, $\mathrm{p}<0.05$ ) (Fig. 2).

FEMALES WITH EMBRYOS AND FECUNDITY

A total of 248 females with embryos was collected: 138 at egg stage I, 55 at stage II and 55 at stage III. The rainy season 2 was the period with the 

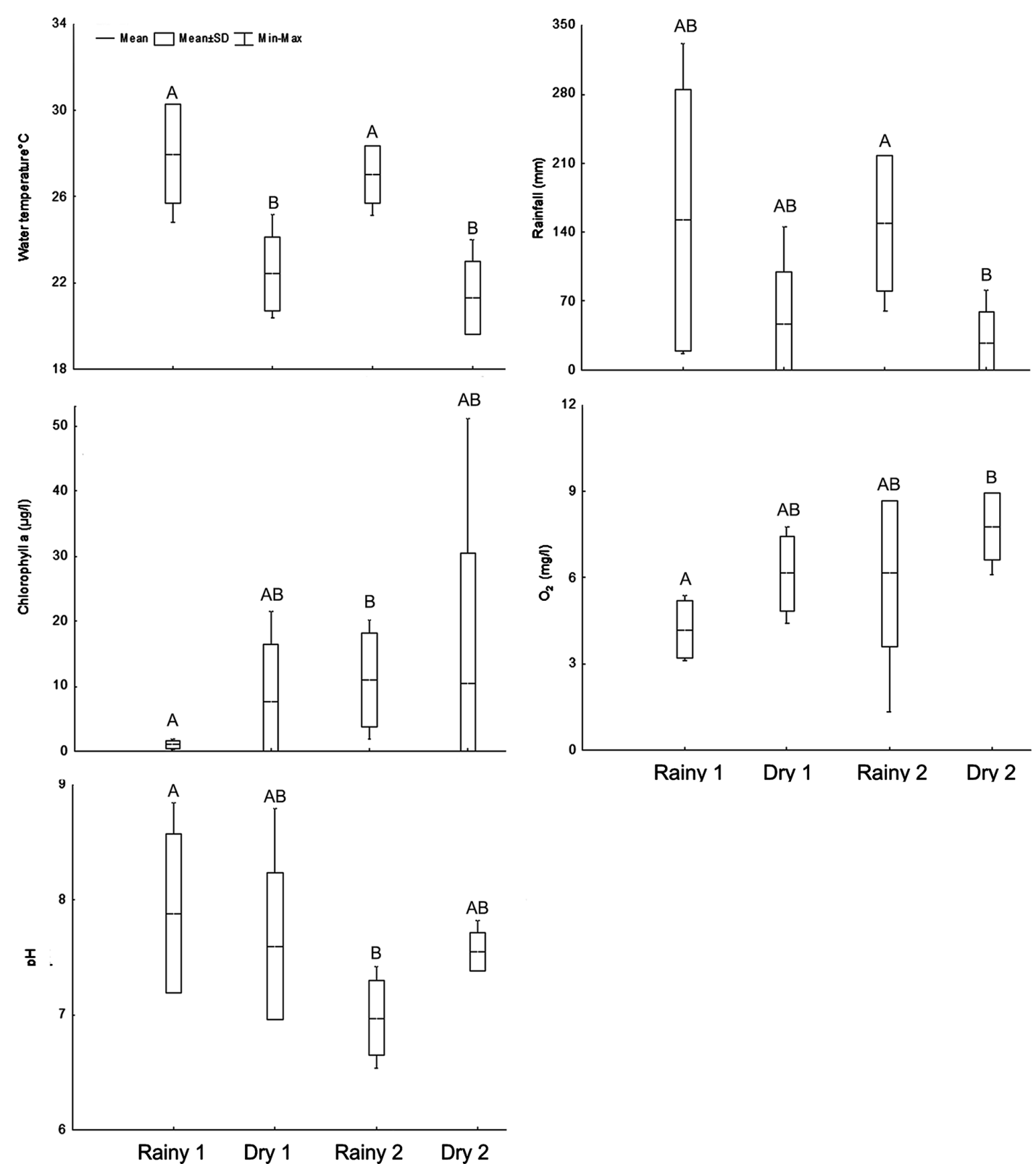

Figure 2 - Mean \pm standart deviation, minimum and maximum values of each environmental factor: water temperature, rainfall, chlorophyll-a and $\mathrm{O}_{2}$ concentration and $\mathrm{pH}$.

highest capture of females (105), while dry season 2 had the lowest capture (31). Complete data about number of females at each ES and season is shown in Table I.

Mean CL was $13.41 \pm 2.13 \mathrm{~mm}$ and ranged from 8.99 to $22.30 \mathrm{~mm}$. There were no statistically significant differences in the CL of females collected among each sampled season (ANOVA, $\mathrm{p}>0.05)$. Fecundity varied from 104 to 4264 eggs (mean 921.21 \pm 621.51 ) (Table I). There was a positive correlation between fecundity and CL (Linear Regression, $\mathrm{p}<0.01$ ).

The ANCOVA showed no statistically significant differences between the ES for the correlation fecundity/female size (CL) (Table II), so we used data from the pulled three egg stages to compare the fecundity among seasons. Statistically 
TABLE I

Fecundity and variation in percentage of females per egg stage (ES) of Macrobrachium amazonicum (Heller, 1862), according to size classes of females with embryos analyzed and sampled season. Results expressed by mean \pm standard deviation.

\begin{tabular}{|c|c|c|c|c|c|c|c|c|}
\hline Season & Size Class & $\mathbf{N}$ & $\begin{array}{c}\text { Mean } \\
\text { fecundity }\end{array}$ & $\begin{array}{l}\text { Minimum } \\
\text { fecundity }\end{array}$ & $\begin{array}{c}\text { Maximum } \\
\text { fecundity }\end{array}$ & & $\mathbf{E S}$ & \\
\hline \multirow{3}{*}{ rainy 1} & $8.9-\mid 11.2$ & 14 & $317 \pm 298$ & 104 & 502 & I: $57 \%$ & II: $7 \%$ & III: $36 \%$ \\
\hline & $11.2-13.5$ & 38 & $503 \pm 279$ & 125 & 1020 & I: $53 \%$ & II: $34 \%$ & III: $13 \%$ \\
\hline & $13.5-\mid 15.8$ & 14 & $908 \pm 300$ & 275 & 1350 & I: $57 \%$ & II: $29 \%$ & III: $14 \%$ \\
\hline \multirow{3}{*}{$(n=67)$} & $15.8-\mid 18.1$ & 1 & 1746 & - & - & I: $100 \%$ & - & - \\
\hline & $18.1-\mid 20.4$ & 0 & - & - & - & - & - & - \\
\hline & $20.4-\mid 22.7$ & 0 & - & - & - & - & - & - \\
\hline \multirow{3}{*}{ dry 1} & $8.9-\mid 11.2$ & 14 & $343 \pm 227$ & 147 & 521 & I: $71 \%$ & II: $7 \%$ & III: $22 \%$ \\
\hline & $11.2-13.5$ & 10 & $480 \pm 275$ & 231 & 994 & I: $50 \%$ & II: $10 \%$ & III: $40 \%$ \\
\hline & $13.5-\mid 15.8$ & 3 & $690 \pm 209$ & 584 & 853 & I: $67 \%$ & II: $33 \%$ & - \\
\hline \multirow{3}{*}{$(\mathrm{n}=31)$} & $15.8-\mid 18.1$ & 4 & $931 \pm 367$ & 666 & 1383 & I: $100 \%$ & - & - \\
\hline & $18.1-20.4$ & 0 & - & - & - & - & - & - \\
\hline & $20.4-22.7$ & 0 & - & - & - & - & - & - \\
\hline \multirow{3}{*}{ rainy 2} & $8.9-\mid 11.2$ & 5 & $503 \pm 384$ & 296 & 692 & I: $60 \%$ & II:20\% & III:20\% \\
\hline & $11.2-13.5$ & 39 & $914 \pm 633$ & 481 & 2520 & I: $56 \%$ & II: $28 \%$ & III: $15 \%$ \\
\hline & $13.5-15.8$ & 46 & $1435 \pm 618$ & 378 & 2328 & I: $46 \%$ & II: $24 \%$ & III: $30 \%$ \\
\hline \multirow{3}{*}{$(\mathrm{n}=105)$} & $15.8-\mid 18.1$ & 13 & $1851 \pm 537$ & 571 & 3136 & I: $62 \%$ & II: $15 \%$ & III: $23 \%$ \\
\hline & $18.1-20.4$ & 1 & 1394 & - & - & - & - & III: $100 \%$ \\
\hline & $20.4-\mid 22.7$ & 1 & 4264 & - & - & - & II: $100 \%$ & - \\
\hline \multirow{3}{*}{ dry 2} & $8.9-\mid 11.2$ & 1 & 367 & - & - & - & - & III: $100 \%$ \\
\hline & $11.2-\mid 13.5$ & 16 & $534 \pm 687$ & 132 & 860 & I: $50 \%$ & II: $31 \%$ & III: $19 \%$ \\
\hline & $13.5-\mid 15.8$ & 13 & $776 \pm 702$ & 421 & 1248 & I: $62 \%$ & II: $7 \%$ & III: $31 \%$ \\
\hline \multirow{3}{*}{$(\mathrm{n}=45)$} & $15.8-\mid 18.1$ & 10 & $1471 \pm 691$ & 499 & 2216 & I: $50 \%$ & II: $20 \%$ & III: $30 \%$ \\
\hline & $18.1-\mid 20.4$ & 5 & $2268 \pm 753$ & 1370 & 2894 & - & - & - \\
\hline & $20.4-\mid 22.7$ & 0 & - & - & - & - & - & - \\
\hline
\end{tabular}

significant differences were found among rainy and dry seasons (Fig. 3).

The fecundity of $M$. amazonicum was negatively correlated with $\mathrm{pH}($ Spearman, $\mathrm{p}<0.05)$, i.e., the highest adjusted mean fecundity values were correlated with a decrease in the $\mathrm{pH}$ (Table III). There were statistically positive correlations among adjusted mean fecundity and values of water temperature, rainfall and chlorophyll-a concentration (Spearman, $\mathrm{p}<0.05$ ). There was no statistically significant correlation between $\mathrm{O}_{2}$ concentration and the adjusted mean fecundity (Spearman, $\mathrm{p}>0.05$ ) (Table III).
EGG VOLUME (EV) AND REPRODUCTIVE OUTPUT (RO)

A significant increase (Kruskal-Wallis, $\mathrm{p}<0.05$ ) in the mean EV was observed among ES (ES1 = $0.1604 \pm 0.03 \mathrm{~mm}^{3} ; \mathrm{ES} 2=0.1773 \pm 0.03$; ES3 $=0.2024 \pm 0.04)($ Table IV), and there was no significant correlation between EV (in each stage) and CL (Linear Regression, $p>0.05$ ). There were no statistically significant differences in the $\mathrm{EV}$ in each ES among the sampled seasons (ANOVA, $p$ $>0.05)$.

Mean RO was $7.4 \%$, with no significant correlation with CL (Linear Regression, $\mathrm{p}>0.05$ ). 
TABLE II

Results of the Covariance analysis (ANCOVA) of the relationship between female size (CL) and fecundity for Macrobrachium amazonicum (Heller, 1862).

\begin{tabular}{|c|c|c|c|c|}
\hline Relationship & Factor (Group) & Par. (log) & $F$ & $p$ \\
\hline \multirow{6}{*}{ Egg stage } & \multirow{2}{*}{ I vs. II } & $a$ & 1.464 & 0.227 \\
\hline & & $b$ & 3.244 & 0.073 \\
\hline & \multirow{2}{*}{ I vs. III } & $a$ & 2.956 & 0.087 \\
\hline & & $b$ & 2.560 & 0.111 \\
\hline & \multirow{2}{*}{ II vs. III } & $a$ & 0.593 & 0.442 \\
\hline & & $b$ & 0.032 & 0.858 \\
\hline \multirow{12}{*}{ Season } & \multirow{2}{*}{ Rainy 1 vs. Dry 1} & $a$ & --- & --- \\
\hline & & $b$ & 6.648 & $0.011^{*}$ \\
\hline & \multirow{2}{*}{ Rainy 1 vs. Rainy 2} & $a$ & 86.675 & $0.000^{*}$ \\
\hline & & $b$ & 0.196 & 0.658 \\
\hline & \multirow{2}{*}{ Rainy 1 vs. Dry 2} & $a$ & 0.802 & 0.372 \\
\hline & & $b$ & 0.169 & 0.681 \\
\hline & \multirow{2}{*}{ Rainy 2 vs. Dry 1} & $a$ & --- & --- \\
\hline & & $b$ & 6.764 & $0.010^{*}$ \\
\hline & \multirow{2}{*}{ Rainy 2 vs. Dry 2} & $a$ & 84.851 & $0.000^{*}$ \\
\hline & & $b$ & 0.896 & 0.345 \\
\hline & \multirow{2}{*}{ Dry 1 vs. Dry 2} & $a$ & --- & --- \\
\hline & & $b$ & 7.500 & 0.007 * \\
\hline
\end{tabular}

* = statistically significant values.

TABLE III

Test results of Spearman correlations between the adjusted mean fecundity values of Macrobrachium amazonicum (Heller, 1862) and the studied environmental factors in Tietê River, State of São Paulo, Brazil.

\begin{tabular}{cccccc}
\hline & $\begin{array}{c}\text { Water } \\
\text { temperature }\end{array}$ & Rainfall & Chlorophyll-a & $\mathbf{O}_{2}$ & $\mathbf{p H}$ \\
\hline $\begin{array}{c}\text { Correlation } \\
\text { coefficient }\end{array}$ & 0.25 & 0.165 & 0.406 & -0.046 & -0.493 \\
$\mathbf{p}$ & $<0.001 *$ & $0.01 *$ & $<0.001 *$ & 0.48 & $<0.001 *$ \\
Number of samples & 256 & 256 & 256 & 256 & 256 \\
\hline
\end{tabular}

$*=$ statistically significant values.

Mean RO in the rainy season 2 was statistically higher than in other seasons (Kruskal-Wallis, $\mathrm{p}<$ 0.05) (Table IV).

\section{DISCUSSION}

The studied population showed statistically significant variation in reproductive performance when exposed to a range of environmental conditions during the studied period. Macrobrachium amazonicum showed to be a flexible species, able to handle not only different environments (for review, see Maciel and Valenti 2009), but also fluctuations in environmental parameters into the same river.

The absence of embryo loss during embryo development is not typical in caridean shrimps (Anger and Moreira 1998), although observed in the specimens captured in the present study. Similarly, such absence was also noted for M. acanthurus (Wiegmann, 1836) (Tamburus et al. 2012), which was explained as a possible mechanism of parental 


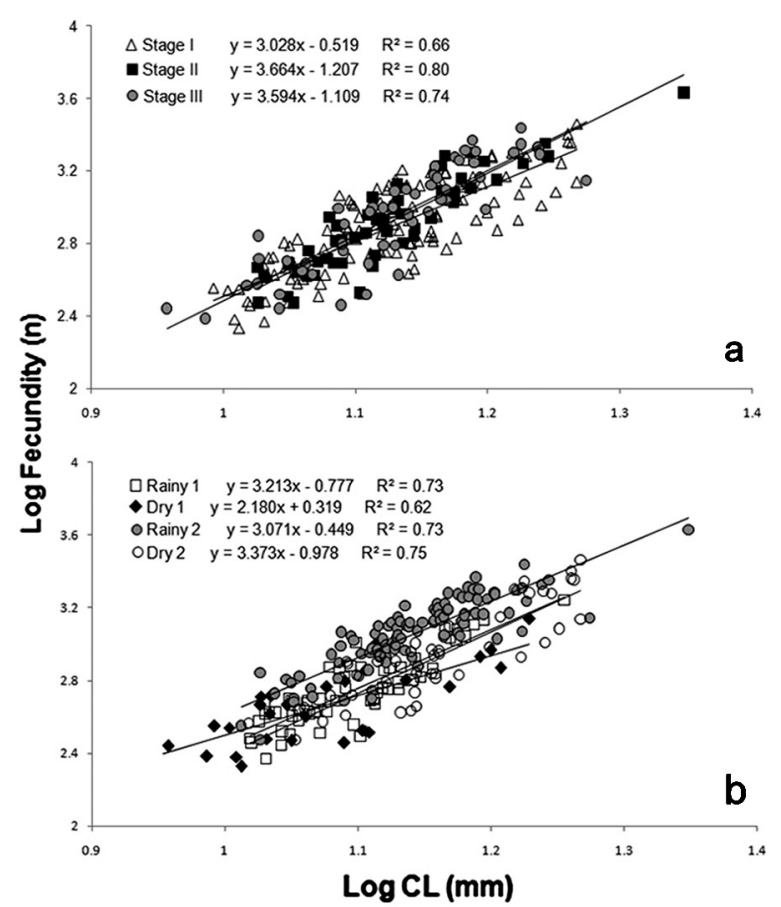

Figure 3 - Correlation between female size (CL) and fecundity of Macrobrachium amazonicum (Heller, 1862) from Tietê River, using as covariable: a) egg stage; b) year season.

care against the most common causes of egg loss (e.g. parasites). Such mechanism is probably part of the grooming behavior. The cleaning of brooded embryos by females is an important type of grooming behavior in many decapod species, which usually use the posterior pereopods with propodal setal brushes to clean the eggs and remove foul particles and parasites (Martin and Felgenhauer 1986). Under experimental conditions, brooded embryos of caridean shrimps not cleaned by females suffered significant mortality (Bauer 1979). Another alternative to avoid embryo loss might be the burrowing behavior, commonly found in many decapod species (Bauer 1979, 1981), including representatives of Macrobrachium Spence Bate, 1868 (Santos et al. 2015).

Our results demonstrated a positive correlation between fecundity and female size in M. amazonicum, which corroborated other studies focusing this species (Lobão et al. 1986, Scaico 1992, Da Silva et al. 2004). Fecundity usually increases with female size in caridean shrimps, decapods, and crustaceans in general (e.g. Reid and Corey 1991, Anger and Moreira 1998, Correa and Thiel 2003, Lara and Wehrtmann 2009, Tamburus et al. 2012, Herrera-Correal et al. 2013).

The observed variations in fecundity, with significantly higher values in the rainy seasons, are probably related to the fluctuations in environmental variables. Water temperature, rainfall and chlorophyll-a values were significantly higher in those periods and were positively correlated with fecundity. Previous studies performed with other crustacean groups - and even with other taxa (e.g. ctenophores, insects and fishes) - have demonstrated that variations in environmental conditions can influence fecundity (Nicola and Almodovar 2002, Leone and Mantelatto 2015, McNamara and Londsdale 2014, Clissold and Simpson 2015, Bourdeau et al. 2016, Wafer et al. 2016).

The Tietê River, along its course, suffers various impacts such as pollution, loss of riparian vegetation, and presence of dams, built mainly for electrical energy generation (Smith et al. 2014). These numerous consecutive dams create a group of reservoirs that receive and accumulate organic and inorganic matter from adjacent systems, with pulses of nutrients concentration in rainy seasons, probably due to runoff (Rodgher et al. 2005, Smith et al. 2014, Esteves et al. 2015). The clutch size of Macrobrachium species is influenced by temporary environmental factors (Mashiko 1990). Therefore, during rainy seasons, the increased temperature and improved feeding conditions due to rainfall, probably stimulated females to invest more energy towards reproduction, increasing fecundity and RO.

When comparing distinct populations of $M$. amazonicum from different locations, an increase in fecundity is usually accompanied by a decrease in egg volume (Maciel and Valenti 2009, Meireles et al. 2013). When studying a population for two years singly, however, we noted a distinct pattern: 
TABLE IV

Variation in the mean egg volume (EV) by egg stage (ES) and reproductive output (RO) of Macrobrachium amazonicum (Heller, 1862), according to year seasons analyzed. Results expressed by Mean \pm Standard deviation. Different letters represent significant differences.

\begin{tabular}{|c|c|c|c|c|c|}
\hline Season & Mean CL & ES & Mean EV & $\%$ (females) & Mean RO (ES I) \\
\hline \multirow{2}{*}{ rainy 1} & & 1 & $0.15 \pm 0.04$ & 55 & \multirow{3}{*}{$5.98 \pm 1.37^{\mathrm{A}}$} \\
\hline & $12.60 \pm 1.59$ & 2 & $0.18 \pm 0.04$ & 27 & \\
\hline$(n=67)$ & & 3 & $0.23 \pm 0.04$ & 18 & \\
\hline \multirow{2}{*}{ dry 1} & & 1 & $0.16 \pm 0.04$ & 68 & \multirow{3}{*}{$5.88 \pm 6.20^{\mathrm{A}}$} \\
\hline & $11.95 \pm 2.14$ & 2 & $0.19 \pm 0.04$ & 10 & \\
\hline$(\mathrm{n}=31)$ & & 3 & $0.21 \pm 0.04$ & 22 & \\
\hline \multirow{2}{*}{ rainy 2} & & 1 & $0.17 \pm 0.03$ & 51 & \multirow{3}{*}{$9.82 \pm 3.95^{\mathrm{B}}$} \\
\hline & $14.03 \pm 1.86$ & 2 & $0.18 \pm 0.03$ & 25 & \\
\hline$(n=105)$ & & 3 & $0.19 \pm 0.03$ & 24 & \\
\hline \multirow{2}{*}{ dry 2} & & 1 & $0.16 \pm 0.03$ & 58 & \multirow{3}{*}{$6.24 \pm 2.82^{\mathrm{A}}$} \\
\hline & $14.90 \pm 2.24$ & 2 & $0.17 \pm 0.03$ & 18 & \\
\hline$(n=45)$ & & 3 & $0.20 \pm 0.03$ & 24 & \\
\hline
\end{tabular}

the increase in fecundity was not followed by increase in egg volume during the studied seasons. This was already proposed for caridean shrimps, in which female overall investment (reproductive output) and investment per offspring (egg size) are not linked, because overall investment is set by conditions experienced by the female, while investment per offspring is related to conditions awaiting newly hatched larvae (Mashiko 1990, Clarke 1993, Hancock 1998). The Ibitinga reservoir is considered a eutrophic system, so high chlorophyll-a concentrations are expected independently of bloom events (Londe et al. 2016). This could explain the absence of increment in egg volume during seasons in the present study, because feeding conditions (plankton) awaiting newly hatched larvae were abundant throughout the year in the studied site.

The CL of females did not correlate statistically with RO. This absence of significant relationship between size and RO seems to be common for Palaemonidae (Zimmermann et al. 2015). The observed values of RO (ranging from $5.98 \pm 1.37$ to $9.82 \pm 3.95$; mean $=7.4 \%$ ) were closer (but still lower) to those found for coastal populations of the species [11.74\% and 10\%, Lima et al. (2014) and Meireles et al. (2013), respectively].

Zimmermann et al. (2015) compiled the data of RO of various Palaemonidae representatives, and the values found for all the other species were also higher than values observed in the present study. These results include other Macrobrachium species: M. hainanense (Parisi, 1919) $10.5 \pm$ $3.8 \%$, studied by Mantel and Dudgeon (2005); $M$. carcinus (Linnaeus, 1758) $12.0 \pm 4.0 \%$, studied by Lara and Wehrtmann (2009); M. acanthurus 19.1 $\pm 4.5 \%$ and $M$. olfersii (Wiegmann, 1836) $21.7 \pm$ $6.6 \%$, studied by Anger and Moreira (1998) [see Table II of Zimmermann et al. (2015), for details]. Continental specimens of $M$. amazonicum usually produce larger eggs because their larvae probably do not have an adequate nutritional source, so they are endowed with food (yolk) to help them subsist during larval development, while coastal females compensate the low energy invested in reproduction by producing a higher number of eggs in each spawn (Meireles et al. 2013). The RO observed in the present study, however, was lower 
than that found for a coastal population by Meireles et al. (2013). It is possible that the great primary production of Ibitinga reservoir, together with a continuous reproduction, allowed females to invest less energy in each brood at Tietê River.

The mean EV significantly increased during developmental stages, although it did not significantly correlated with $\mathrm{CL}$ in. This fact was already recorded for the studied species and for other representatives of Macrobrachium (e.g. Odinetz-Collart and Rabelo 1996, Lara and Wehrtmann 2009, Tamburus et al. 2012, Lima et al. 2014), suggesting that increase in egg volume during development in this genus is independent of the female size. The increase in size and volume during egg development seems to be a common feature among crustaceans (Zimmermann et al. 2015, Moraes et al. 2017) and is a result of gradual water uptake during embryogenesis (Pandian 1970, Lardies and Wehrtmann 1997, Lara and Wehrtmann 2009).

Some shrimp populations from ParanáParaguay basin (those from Pantanal region) were recently described as a separate endemic species, Macrobrachium pantanalense Dos Santos, Hayd and Anger, 2013. Considering that some previously studied populations are now M. pantanalense, we decided here to use M. amazonicum sensu stricto in Table V to compare the various populations studied to the date.

A general pattern for females in relation to body size, fecundity and egg volume can be identified (Table V). Continental populations are generally smaller, exhibit lower fecundities and higher egg volumes, when compared to coastal females. The population studied here, however, did not follow this pattern for some studied reproductive traits. Concerning size and fecundity, females from Tietê River showed the highest values ever recorded for a continental population, and they can be considered intermediate or similar to those of coastal populations. Regarding egg volume, once more specimens from the present study showed values closer to coastal populations. These differences in reproductive traits of Tietê River specimens compared to other continental populations are probably related to the high availability of nutrients in the studied site, as demonstrated by the analysis of photosynthetic pigments (chlorophyll-a concentrations up to $51.8 \mu \mathrm{g} / \mathrm{l})$. Differences in reproductive parameters between coastal and continental populations were already attributed primarily to the hydrological and geographical particularities of each location. Such differences can directly influence the life history of each population, more than latitudinal differences (Meireles et al. 2013).

In a previous study at the same sampling site, Pantaleão et al. (2014) reported a strong human disturbance in this stretch of Tietê River. Such disturbance is caused by an excessive external supply of nutrients, as fish food (pellets), viscera of caught fish and corn, to attract fish for sport fishing. The occurrence of the four male morphotypes described for M. amazonicum (Moraes-Riodades and Valenti 2004) was recorded for the first time in a continental population (Pantaleão et al. 2014) in the same sampling location, and the authors attributed this occurrence to the great availability of nutrients in Tietê River. Considering the characteristics of the studied locality (high concentrations of solid nutrients and chlorophyll-a), we can affirm that our results support the hypothesis of Pantaleão et al. (2014), in which the differences in reproductive parameters between coastal and continental populations were mainly related to the availability of nutrients.

As illustrated here, reproductive parameters of $M$. amazonicum differed markedly between continental and coastal populations. These differences are sometimes interpreted as evidence of speciation process between these groups. When studying seven populations of the species in the Amazon Basin, Odinetz-Collart and Rabelo 
TABLE V

Maximum carapace length (CL), maximum fecundity, and mean egg volume (EV, at stage 1, when data was available) of Macrobrachium amazonicum (Heller, 1862) females of distinct populations living at different types of environment.

\begin{tabular}{|c|c|c|c|c|c|c|c|}
\hline \multicolumn{2}{|c|}{$\begin{array}{c}\text { Type of } \\
\text { environment }\end{array}$} & $\underset{(\mathrm{mm})}{\operatorname{Maximum} \mathrm{CL}}$ & $\begin{array}{l}\text { Maximum } \\
\text { fecundity }\end{array}$ & $\underset{\left(\mathrm{mm}^{3}\right)}{\text { Egg volume }}$ & Locality & Longitude & Reference \\
\hline \multirow{9}{*}{ 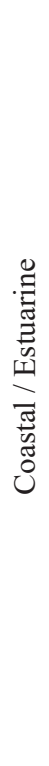 } & \multirow{6}{*}{ 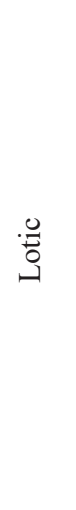 } & 16.2 & 2,200 & 0.14 & Ceará, Brazil & $38^{\circ} 51^{\prime}$ & Guest 1979 \\
\hline & & 19.4 & 1,277 & 0.11 & $\begin{array}{l}\text { Amazon River, } \\
\text { Brazil }\end{array}$ & - & $\begin{array}{l}\text { Kensley and } \\
\text { Walker } 1982\end{array}$ \\
\hline & & - & 1,344 & - & Pará, Brazil & $48^{\circ} 30^{\prime}$ & Lobão et al. 1986 \\
\hline & & 26.0 & 5,706 & - & $\begin{array}{l}\text { Tocantins River, } \\
\text { Pará, Brazil }\end{array}$ & $49^{\circ} 29^{\prime}$ & $\begin{array}{c}\text { Odinetz-Collart } \\
\text { and Magalhães } \\
1994\end{array}$ \\
\hline & & - & 3,375 & - & Pará, Brazil & $48^{\circ} 45^{\prime}$ & $\begin{array}{l}\text { Lucena-Frédou } \\
\text { et al. } 2010\end{array}$ \\
\hline & & 29.6 & 7,417 & 0.12 & $\begin{array}{l}\text { Amazon River, } \\
\text { Amapá, Brazil }\end{array}$ & $51^{\circ} 08^{\prime}$ & Lima et al. 2014 \\
\hline & \multirow{3}{*}{. } & - & 2,673 & 0.11 & $\begin{array}{c}\text { Pernambuco, } \\
\text { Brazil }\end{array}$ & $37^{\circ} 97^{\prime}$ & $\begin{array}{l}\text { L.A. Vega-Pérez, } \\
\text { unpublished data }\end{array}$ \\
\hline & & - & 2,193 & - & Ceará, Brazil & $37^{\circ} 49^{\prime}$ & $\begin{array}{c}\text { Da Silva et al. } \\
2004\end{array}$ \\
\hline & & $19.4 *$ & 2,956 & 0.13 & Pará, Brazil & $48^{\circ} 32^{\prime}$ & $\begin{array}{c}\text { Meireles et al. } \\
2013\end{array}$ \\
\hline \multirow{5}{*}{ 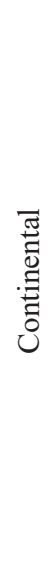 } & 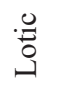 & 22.3 & 4,264 & 0.16 & $\begin{array}{c}\text { Tietê River, São } \\
\text { Paulo, Brazil }\end{array}$ & $49^{\circ} 01^{\prime}$ & Present study \\
\hline & \multirow{4}{*}{. } & - & 2,259 & 0.39 & $\begin{array}{c}\text { Lakes of } \\
\text { Amazon River, } \\
\text { Brazil }\end{array}$ & $60^{\circ} 01^{\prime}$ & Magalhães 1985 \\
\hline & & 18.0 & 2,165 & - & $\begin{array}{c}\text { Lakes of } \\
\text { Amazon River, } \\
\text { Brazil }\end{array}$ & $59^{\circ} 48^{\prime}$ & $\begin{array}{c}\text { Odinetz-Collart } \\
1991\end{array}$ \\
\hline & & 18.0 & 617 & - & $\begin{array}{c}\text { Dam of } \\
\text { Tocantins River, } \\
\text { Pará, Brazil }\end{array}$ & $49^{\circ} 38^{\prime}$ & $\begin{array}{c}\text { Odinetz-Collart } \\
\text { and Magalhães } \\
1994\end{array}$ \\
\hline & & 18.0 & 2,850 & - & $\begin{array}{c}\text { Lakes of } \\
\text { Amazon River, } \\
\text { Brazil }\end{array}$ & $59^{\circ} 48^{\prime}$ & $\begin{array}{l}\text { Odinetz-Collart } \\
\text { and Magalhães } \\
1994\end{array}$ \\
\hline
\end{tabular}

* = mean values. Egg volume estimated by egg size data, when necessary.

(1996) noted differences in reproductive features between these groups, and suggested a progressive divergence of this species from a typical littoral population to an inland form in a still active adaptive process. The continental population studied here, however, exhibits reproductive characteristics that can be considered closer to those of coastal populations.
A possible explanation for the differences in reproductive traits found in the present study, when compared with other continental populations, is that $M$. amazonicum is not native of Tietê River. The species was probably introduced between 1966 and 1973, together with M. jelskii (Miers, 1877 ) at the CESP (Companhia Energética de São Paulo) fish-farming stations, as part of the process 
of transplanting of the Sciaenidae fish Plagioscion squamosissimus (Heckel, 1840) from reservoirs of northeastern Brazil (Torloni et al. 1993, Magalhães et al. 2005). Thus, shrimp from Tietê River were relatively recently introduced, and are originate from a coastal population, which was confirmed by genetic data (Vergamini et al. 2011). Regardless of the fact some continental populations are under speciation process, our results confirm a great plasticity of the species, since even completing the entire life cycle in freshwater, females exhibit reproductive features similar to those of coastal populations, and males develop into four morphotypes (Pantaleão et al. 2014).

The correlation found in the present study between reproductive parameters and environmental variables corroborates the affirmation in which the wide variation in population and reproductive parameters observed among the geographical distribution of $M$. amazonicum are related to the environmental characteristics that each population is inserted (Pantaleão et al. 2012, 2014, Meireles et al. 2013). Thus, we suggest that further studies investigate the potential of continental populations of $M$. amazonicum for aquaculture, because continental populations can show fecundity values and reach body sizes similar to those of coastal populations, which are generally used for commercial cultivation. The cultivation of populations with an entirely freshwater life cycle would significantly reduce the costs of production.

\section{ACKNOWLEDGMENTS}

To Conselho Nacional de Desenvolvimento Científico e Tecnológico (CNPq) (Research Scholarship PQ Nº. 305919/2014-8 awarded to Rogério Caetano da Costa) and Coordenação de Aperfeiçoamento de Pessoal de Nível Superior (CAPES) for the award of doctoral scholarships for João Alberto Farinelli Pantaleão, Abner Carvalho
Batista and Sarah de Souza Alves Theodoro. We are thankful to members of the LABCAM for their help during laboratorial analyses. We also thank the anonymous reviewers for their valuable comments and suggestions to improve the quality of the paper. João Alberto Farinelli Pantaleão would like to thank his grandfather Mr. Antônio Fraga da Silva (in memoriam), who indicated the sampling site and helped during fieldwork. Prawns in this study were collected according to Brazilian laws concerning sampling of wild animals.

\section{REFERENCES}

ANGER K AND MOREIRA GS. 1998. Morphometric and reproductive traits of tropical caridean shrimps. J Crustacean Biol 18: 823-838.

BAUER RT. 1979. Antifouling adaptations of marine shrimp (Decupoda: Caridea): gill cleaning mechanisms and grooming of brooded embryos. Zool J Linn Soc 65: 281303.

BAUER RT. 1981. Grooming behavior and morphology in the Decapod Crustacea. J Crustacean Biol 1: 153-173.

BOURDEAU PE, BACH MT AND PEACOR SD. 2016. Predator presence dramatically reduces copepod abundance through condition-mediated non-consumptive effects. Freshwater Biol 61: 1020-1031.

CLARKE A. 1993. Reproductive trade-offs in caridean shrimps. Funct Ecol 7: 411-419.

CLARKE A, HOPKINS CCE AND NILSSEN EM. 1991. Egg size and reproductive output in the deep water prawn Pandalus borealis (Kroyer, 1838). Funct Ecol 5: 724-730.

CLISSOLD FJ AND SIMPSON SJ. 2015. Temperature, food quality and life history traits of herbivorous insects. Curr Opin Insect Sci 11: 63-70.

CORREA C AND THIEL M. 2003. Mating systems in caridean shrimp (Decapoda: Caridea) and their evolutionary consequences for sexual dimorphism and reproductive biology. Rev Chil Hist Nat 76: 187-203.

COSTA TM AND NEGREIROS-FRANSOZO ML. 1998. The reproductive cycle of Callinectes danae Smith, 1869 (Decapoda, Portunidae) in the Ubatuba region, Brazil. Crustaceana 71: 615-627.

DA SILVA RR, SAMPAIO CMS AND SANTOS JA. 2004. Fecundity and fertility of Macrobrachium amazonicum (Crustacea, Palaemonidae). Braz J Biol 64: 489-500.

ESTEVES KE, LÔBO AVP AND HILSDORF AWS. 2015 Abiotic features of a river from the Upper Tietê River Basin (SP, Brazil) along an environmental gradient. Acta Limnol Bras 27: 228-237. 
FRANCHITO SH, RAO VB, BARBIERI PRP AND SANTO CME. 2008. Rainy season duration estimated from OLR vs. raingauge data and the 2001 drought in Southeast Brazil. J Appl Meteorol Climatol 47: 1493-1499.

GARCÍA-GUERRERO MU AND HENDRICKX ME. 2009. External description of the embryonic development of the prawn, Macrobrachium americanum Bate, 1868 (decapoda, palaemonidae) based on the staging method. Crustaceana 82: 1413-1422.

GOLTERMAN HL, CLYMO RS AND OHSTAD M. 1978. Methods for physical \& chemical analysis of freshwater, $n$. 8. Blackwell Scientific Publications: Oxford, $230 \mathrm{p}$.

GUEST WC. 1979. Laboratory life history of the palaemonid shrimp Macrobrachium amazonicum (Heller) (Decapoda, Palaemonidae). Crustaceana 37: 141-152.

HANCOCK MA. 1998. The relationship between egg size and embryonic and larval development in the freshwater shrimp Paratya australiensis Kemp (Decapoda: Atyidae). Freshwater Biol 39: 715-723.

HERRERA-CORREAL J, MOSSOLIN EC, WEHRTMANN IS AND MANTELATTO FL. 2013. Reproductive aspects of the caridean shrimp Atya scabra (Leach, 1815) (Decapoda: Atyidae) in São Sebastião Island, southwestern Atlantic, Brazil. Lat Am J Aquat Res 41: 676-684.

HINES AH. 1982. Allometric constraints and variables of reproductive effort in brachyuran crabs. Mar Biol 69: 309320.

JEPPESEN E ET AL. 2015. Ecological impacts of global warming and water abstraction on lakes and reservoirs due to changes in water level and related changes in salinity. Hydrobiologia 750: 201-227.

KENSLEY B AND WALKER I. 1982. Palaemonid shrimps from the Amazon basin (Crustacea: Decapoda: Natantia). Smithson Contrib Zool 362: 1-28.

LARA LR AND WEHRTMANN IS. 2009. Reproductive biology of the freshwater shrimp Macrobrachium carcinus (L.) (Decapoda: Palaemonidae) from Costa Rica, Central America J Crustacean Biol 29: 343-349.

LARDIES MA AND WEHRTMANN IS. 1997. Egg production in Betaeus emarginatus (H. Milne Edwards, 1837) (Decapoda: Alpheidae): fecundily, reproductive output and chemical composition of eggs. Ophelia 46: 165-174.

LEONE IC AND MANTELATTO FL. 2015. Maternal investment in egg production: Substrate and populationspecific effects on offspring performance of the symbiotic crab Pachycheles monilifes (Anomura: Porcellanidae). J Exp Mar Biol Ecol 464: 18-25.

LIMA JF, SILVA LMA, SILVA TC, GARCIA JS, PEREIRA IS AND AMARAL KDS. 2014. Reproductive aspects of Macrobrachium amazonicum (Decapoda: Palaemonidae) in the State of Amapá, Amazon River mouth. Acta Amaz 44: $245-254$.
LOBÃO VL, ROJAS NET AND VALENTI W. 1986. Fecundidade e fertilidade de Macrobrachium amazonicum (Heller, 1862) (Crustacea, Decapoda) em laboratório. Bol Inst Pesca 13: 15-20.

LONDE LR, NOVO EMLM, BARBOSA C AND ARAUJO CAS. 2016. Water residence time affecting phytoplankton blooms: study case in Ibitinga Reservoir (São Paulo, Brazil) using Landsat/TM images. Braz J Biol 76: 664672.

LUCENA-FRÉDOU F, ROSA JS, SILVA MCN AND AZEVEDO EF. 2010. Population dynamics of the river prawn, Macrobrachium amazonicum (Heller, 1862) (Decapoda, Palaemonidae) on Combu island (Amazon estuary). Crustaceana 83: 277-290.

MACIEL CR AND VALENTI WC. 2009. Biology, fisheries and aquaculture of the Amazon River Prawn Macrobrachium amazonicum: a review. Nauplius 17: 6179.

MAGALHÃES C. 1985. Desenvolvimento larval obtido em laboratório de palaemonídeos da região Amazonica. I. Macrobrachium amazonicum (Heller, 1862) (Crustacea, Decapoda). Amazoniana 9: 247-274.

MAGALHÃES C, BUENO SLS, BOND-BUCKUP G, VALENTI WC, SILVA HLM, KIYOHARA F, MOSSOLIN EC AND ROCHA S. 2005. Exotic species of freshwater decapod crustaceans in the state of São Paulo, Brazil: records and possible causes of their introduction. Biodivers Conserv 14: 1929-1945.

MANTEL SK AND DUDGEON D. 2005. Reproduction and sexual dimorphism of the palaemonid shrimp Macrobrachium hainanense in Hong Kong streams. J Crustacean Biol 25: 450-459.

MARTIN JW AND FELGENHAUER BE. 1986. Grooming behaviour and the morphology of grooming appendages in the endemic South American crab genus Aegla (Decapoda, Anomura, Aeglidae). J Zool London 209: 213-224.

MASHIKO K. 1990. Diversified egg and clutch sizes among local populations of the fresh-water prawn Macrobrachium niponense (de Haan). J Crustacean Biol 10: 306-314.

MCNAMARA ME AND LONSDALE DJ. 2014. Interannual differences in microplankton drive changes in the feeding and fecundity of Mnemiopsis leidyi in a Long Island estuary. Estuar Coast Shelf Sci 144: 1-7.

MEEHL GA ET AL. 2007. Global climate projections. In: Solomon S et al. (Eds), Climate Change 2007: the Physical Science Basis. Contribution of Working Group I to the Fourth Assessment Report of the Intergovernmental Panel on Climate Change, Cambridge University Press: Cambridge, p. 749-844.

MEIRELES AL, VALENTI WC AND MANTELATTO FL. 2013. Reproductive variability of the Amazon River prawn, Macrobrachium amazonicum (Caridea, Palaemonidae): 
influence of life cycle on egg production. Lat Am J Aquat Res 41: 718-731.

MORAES IRR, WOLF MR, GONÇALVES GRL AND CASTILHO AL. 2017. Fecundity and reproductive output of the caridean shrimp Periclimenes paivai associated with scyphozoan jellyfish. Invertebr Reprod Dev 61: 71-77.

MORAES-RIODADES PMC AND VALENTI WC. 2004. Morphotypes in male Amazon River Prawns, Macrobrachium amazonicum. Aquaculture 236: 297-307.

MORAES-VALENTI P AND VALENTI WC. 2010. Culture of the Amazon River Prawn Macrobrachium amazonicum. In: New et al. (Eds), Freshwater prawns: biology and farming, Wiley: Chichester, p. 485-581.

NICOLA GG AND ALMODÓVAR A. 2002. Reproductive traits of stream-dwelling brown trout Salmo trutta in contrasting neighbouring rivers of central Spain. Freshwater Biol 47: 1353-1365.

ODINETZ-COLLART O. 1991. Strategie de reproduction de Macrobrachium amazonicum en Amazonie Centrale (Decapoda, Caridea, Palaemonidae). Crustaceana 61: 253270.

ODINETZ-COLLART O. 1993. Ecologia e potencial pesqueiro do camarão-canela Macrobrachium amazonicum na Bacia Amazônica. In: Ferreira EJG et al. (Eds), Bases científicas para estratégias de preservação e desenvolvimento da Amazônia: fatos e perspectivas, INPA: Manaus, p. 147166.

ODINETZ-COLLART O AND MAGALHÃES C. 1994. Ecological constraints and life history of palaemonid prawns in Amazonia. Verh Internat Verein Limnol 25: 2460-2467.

ODINETZ-COLLART O AND RABELO H. 1996. Variation in egg size of the fresh-water prawn Macrobrachium amazonicum (Decapoda: Palaemonidae). J Crustacean Biol 16: 684-688.

PANDIAN TJ. 1970. Ecophysiological studies on the developing eggs and embryos of the European lobster Homarus gammarus. Mar Biol 5: 154-167.

PANTALEÃO JAF, HIROSE GL AND COSTA RC. 2012. Relative growth, morphological sexual maturity, and size of Macrobrachium amazonicum (Heller, 1862) (Crustacea, Decapoda, Palaemonidae) in a population with an entirely freshwater life cycle. Invertebr Reprod Dev 56: 180-190.

PANTALEÃO JAF, HIROSE GL AND COSTA RC. 2014. Occurrence of male morphotypes of Macrobrachium amazonicum (Caridea, Palaemonidae) in a population with an entirely freshwater life cycle. Braz J Biol 74: 223-232.

REID DM AND COREY S. 1991. Comparative fecundity of decapod crustaceans. III. The fecundity of fifty-three species of Decapoda from tropical, subtropical and boreal waters. Crustaceana 61: 308-316.
RODGHER S, ESPÍNDOLA ELG, ROCHA O, FRACÁCIO R, PEREIRA RHG AND RODRIGUES MHS. 2005. Limnological and Ecotoxicological Studies in the Cascade of Reservoirs in the Tietê River (São Paulo, Brazil). Braz J Biol 65: 697-710.

SANTOS DB, PONTES CS, CAMPOS PMO AND ARRUDA MF. 2015. Behavioral profile of Macrobrachium rosenbergii in mixed and monosex culture submitted to shelters of different colors. Acta Sci - Biol Sci 37: 273-279.

SCAICO MA. 1992. Fecundidade e fertilidade de Macrobrachium amazonicum (Crustacea, Decapoda) de um açude do Nordeste Brasileiro. Bol Inst Pesca 19: 89-96.

SMITH WS, ESPÍNDOLA ELG AND ROCHA O. 2014. Environmental gradient in reservoirs of the medium and low Tietê River: limnological differences through the habitat sequence. Acta Limnol Bras 26: 73-88.

TAMBURUS AF, MOSSOLIN EC AND MANTELATTO FL. 2012. Populational and reproductive aspects of Macrobrachium acanthurus (Wiegmann, 1836) (Crustacea: Palaemonidae) from north coast of São Paulo state, Brazil. Braz. J Aquat Sci Technol 16: 9-18.

TORLONI CEC, SANTOS JJ, CARVALHO JR AA AND CORRÊA ARA. 1993. A pescada-do-Piauí Plagioscion squamosissimus (Heckel, 1840) (Osteichthyes, Perciformes) nos reservatórios da Companhia Energética de São Paulo - CESP. CESP, São Paulo, 23 p.

VERGAMINI FG, PILEGGI LA AND MANTELATTO FL. 2011. Genetic variability of the Amazon River prawn Macrobrachium amazonicum (Decapoda, Caridea, Palaemonidae). Contrib Zool 80: 67-83.

WAFER LN, JENSEN VB, WHITNEY JC, GOMEZ TH, FLORES R AND GOODWIN B. 2016. Effects of Environmental Enrichment on the Fertility and Fecundity of Zebrafish (Danio rerio). J Am Assoc Lab Anim Sci 55: 291-294.

WEHRTMANN IS. 1990. Distribution and reproduction of Ambidexter panamense and Palaemonetes schmitti in Pacific Costa Rica (Crustacea, Decapoda). Rev Biol Trop 38: 327-329.

YOSHINO K, GOSHIMA S AND NAKAO S. 2002. Temporal reproductive patterns within a breeding season of the hermit crab Pagurus filholi: effects of crab size and shell species. Mar Biol 141: 1069-1075.

ZAR JH. 1999. Biostatistical analysis. New Jersey: Prentice Hall, 663 p.

ZIMMERMANN U, CARVALHO FL AND MANTELATTO FL. 2015. The reproductive performance of the Red-Algae shrimp Leander paulensis (Ortmann, 1897) (Decapoda, Palaemonidae) and the effect of post-spawning female weight gain on weight-dependent parameters. Braz J Ocean 63: 207-216. 